Research Articles

\title{
Influence of Foreign Direct Investment on Gross Domestic Product; an Empirical Study of Pakistan
}

\author{
Muddassar Sarfraz and Shuangqin Liu \\ School of Business, Hohai University, Nanjing, Jiangsu, PR China
}

Article history

Received: 28-05-2015

Revised: 09-07-2015

Accepted: 09-07-2015

Corresponding Author: Muddassar Sarfraz

School of Business, Hohai

University, Nanjing, Jiangsu, PR China

Tel: +86(182)0519-7147

Email: muddassar.sarfraz@gmail.com

\begin{abstract}
Empirical study was conducted to assess the relationship and impact of Foreign Direct Investment (FDI) on the economic growth of Pakistan. FDI plays critical role in the development of economy. There is a positive relationship between the Gross Domestic Product (GDP) and Foreign Direct Investment (FDI). With the increase of FDI, GDP of the country also increases. It has been observed that in the developing countries GDP growth is more dependent on foreign direct investment. People Republic of China is from one of the recent examples. Chinese companies are investing a large amount in the different sectors of Pakistan. FDI is boosting country GDP and attracting multinationals organizations towards making investment in the country. It is found that world see Pakistan as an important destination for outward FDI projects because of its cheap labor cost, strategic location and investment incentives. It is expected that this research will be helpful to investors to comprehend an overall investment scenario as well as government policy makers to take necessary steps for creating a favourable investment climate for foreign investors in Pakistan. It has been observed that in 2012 , there is $11.9 \%$ decrease in financial assets and direct Investment has increased by $10.6 \%$. Direct Investment is $6.6 \%$ of total assets. Till 2011, Direct Investment in Pakistan was US \$20,916 million but in 2012, with the increase of US\$ 2,209 million it became US\$23,126 million. During 2012, portfolio investment increased $24.1 \%$.
\end{abstract}

Keywords: Gross Domestic Product, Foreign Direct Investment, Pakistan, GDP, FDI

\section{Introduction}

Foreign Direct Investment (FDI) is an experience resulting from globalization, which creates opportunity to amalgamate the domestic economic system with international markets. As compared to other forms of capital flows, FDI is increasingly becoming a preferred form of capital flows to developing countries because FDI promises to be the bright ray of hope for exploiting capital flows to the country's economic development without the cramps of capital repayment. FDI is measured as one of the crucial determinants for enhancing the economic growth as well as the overall development of a country, especially in developing country because of its ability to deal with two major obstacles such as the shortages of financial resources and technology \& skills. As a developing country, Pakistan suffers from the shortage of financial resources and lack of technology to boost up her economy. Basically
Pakistan is an agro-based country, but industrial development is an important pre-requisite for her economic development. So Pakistan is gradually moving from agrarian economy to industrial economy. Government of Pakistan is trying to create a favorable investment environment through promoting privatization, introducing economic policies, incentives for foreign investors and so on.

Pakistan must be a potential business hub for the world, more especially Chinese investors because many of them have visited the country for that purpose in last few years. Investors have showed keen interest to increase investment especially in textiles, agroprocessing, energy and power, pharmaceuticals, communications and infrastructure development. Pakistani Prime Minister Nawaz Sharif invited different countries companies to invest in Pakistan and promised investors would find good government support. 
Pakistan offers immense investment potentials with high return for investors.

This paper will analyze impact and relationship between foreign direct investment and gross domestic product. Pakistan is land of opportunities and probably one of the most attractive places for investment and doing business in world. Country has opened its doors for investment and warmly welcomed organizations across the world. Government is introducing new polies for FDI. Government is strongly committed to bring economic reforms in the country. Might be process is not as fast as it should be but commitment is behind it. Foreign direct investment can be source of transformation of technology and knowledge (Dunning and Hamdani, 1997).

\section{Literature Review}

According to the World Investment Report (WIR, 1999) of the United Nations Conference on Trade and Development (UNCTAD), "FDI as an investment involving a long- term relationship and reflecting a lasting interest and control of a resident entity in one economy (foreign direct investor or parent enterprise) in an enterprise resident in a diplomacy." Reza et al. (1987) conducted a study and defined FDI as investment by multinational corporations in foreign countries in order to control assets and manage production activities in those countries. Foreign Direct Investment can be defined as investment in which a firm acquires a substantial controlling interest in a foreign firm or set up a subsidiary in a foreign country (Chen, 2000). Trade can play vital role in the development of countries (Agrawal, 2000). In the development of economic growth of a country, government policy is not only key factor by which it can attract foreign capital but also export promotion startegy is important (Ahmad et al., 2003).

There are two common elements of FDI. Firstly, it involves at least two countries and secondly, it deals with issue of ownership and control of production activities in a foreign country. A country's economic development depends upon FDI inflows. Host countries may be increased this inflow through tax incentives (Piggott and Cook., 1999). Mian and Alam (2006) stated that a country's FDI inflow is being restricted by infrastructural, bureaucratic and environmental complicacy. John H. Dunning's paradigm concludes that there are three primary motivations which lead to FDI by any country: Natural resource-seeking, market-seeking and efficiency-seeking (Sethi et al., 2003). Foreign Direct Investment can helps to raise domestic capital, employment opportunity, build up organizational formation of the host country. It also helps to get better domestic and foreign marketing network and assist to improve the technical expertise of the Government. Kumar (2002) stated that FDI has emerged as the most important source of external finances and resources to developing countries over the 1990s. Findlay (1978) stated that FDI has an infectious effect on advanced technology management and practices. Caves (1996) examines that FDI has positive impact on productivity gains, technology transfer, the introduction of new processes, managerial skills in the domestic market. Mottaleb (2007) points out that FDI provides economic benefits to the host country by creating employment opportunities, providing physical capital, technology and enhancing access to international markets.

A study was conducted on the FDI impact on Pakistan economy Falki (2009). Data which was used in this study gathered from the handbook on Pakistan economy 2005. Domestic and Foreign variables was used. As a result it states that FDI have negative impact on GDP. FPI and external loans has a positive impact on the growth of real GDP (Shabbir and Mahmood, 1992). There is positive realtionship between GDP and FDI but negative relationship between GDP and inflation (Gudaro et al., 2010). Herzer et al. (2008) has argued that there are 28 developing countries does not exit any data related to short or long term effect of FDI on growth. Moosa (2002) identifies during the surveys of foreign direct investment that the implied explanatory variables in the process, as well as variables that cannot be readily related to any of these theories.FDI has positive impact on short run-long run GDP grwoth, if domestic financial system has achieved enough development (Muhammad, 2007).

\section{Doing Business in Pakistan}

Pakistan is a developing country and nation is facing some serious challenges those can affect economy of country. One of the key challenges is terrorism and political instability. Even though country is fighting hard to overcome these challenges in last few years.

On the scale of doing business, Pakistan ranks at 110 on the scale of 189 . Due to electricity problem in the country, it stands on 175 which are the lowest as comparison with others. On the other side protecting investors is higher. Government is making some reforms so foreign investors can come and play their role in the development of economy. Chinese companies are the biggest investors in the country till now and they have planned to do more investment in the different sectors of the country. Due to cheap labor, low cost production and other different facilities are the main sources of FDI in the country.

\section{Foreign Direct Investment in Pakistan}

Pakistan is a fast developing country. Government policies are encouraging foreign direct investment in the country. Due to change in policies and more friend investment now country rank at 97 th position (Baseline 
Profitability index) in the world. In 2011, net foreign direct investment in the country was $(\$ 1,246,770,000.00)$.

It has been observed that over the last 6 years the value has fluctuated between $(\$ 1,246,770,000.00)$ in 2011 and $(\$ 5,492,000,000.00)$ in 2007. In 2013, Inflation rate in the country was $7.7 \%$.

In 2011, FDI, net flows (BoP, current US \$) was $2,018,000,000$ and in $2013,1,307,000,000$. Although there are challenges for foreign investments in Bangladesh, there are also several opportunities. Since Pakistan has enough cheap labor, particularly in the Agriculture sector, World should utilize it. The energy sector can be another area for foreign investments since the energy demand of the country is growing and Pakistan is rich in energy resources. According to experts country has lot of potential for energy due to its strategic position. This huge volume of energy reserves can be an opportunity for further foreign investments (Fig. 1 and 2).

\section{Economic ranking on the ease of doing business}

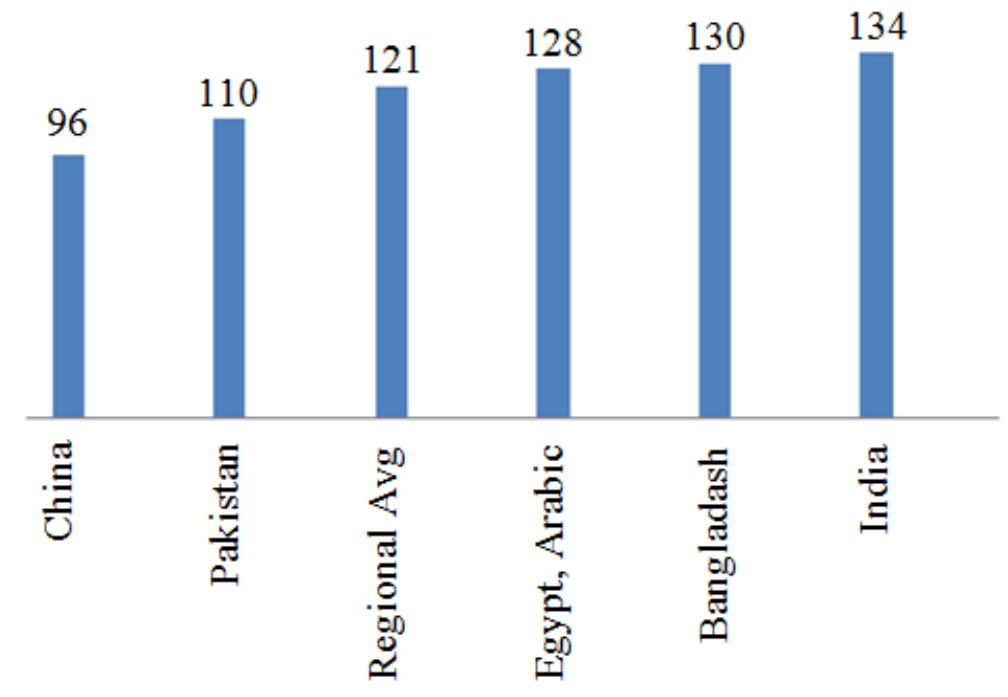

Fig. 1. Source: Doing Business database

\section{Pakistan ranking on doing business}

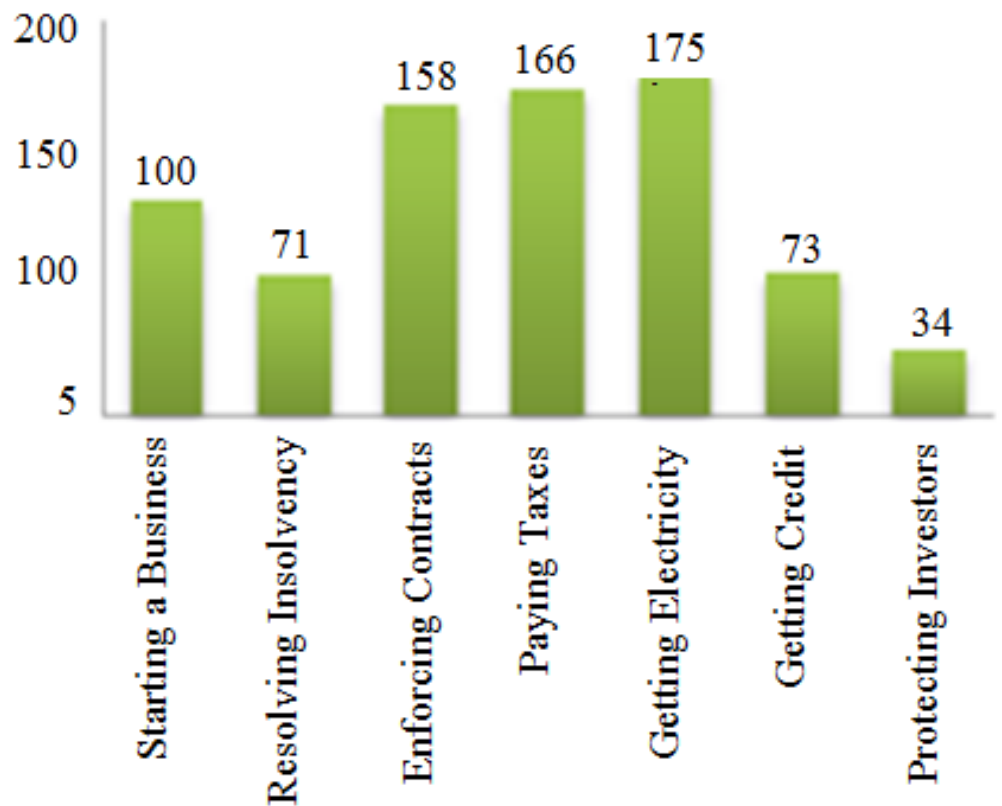

Fig. 2. Source: Doing Business database 


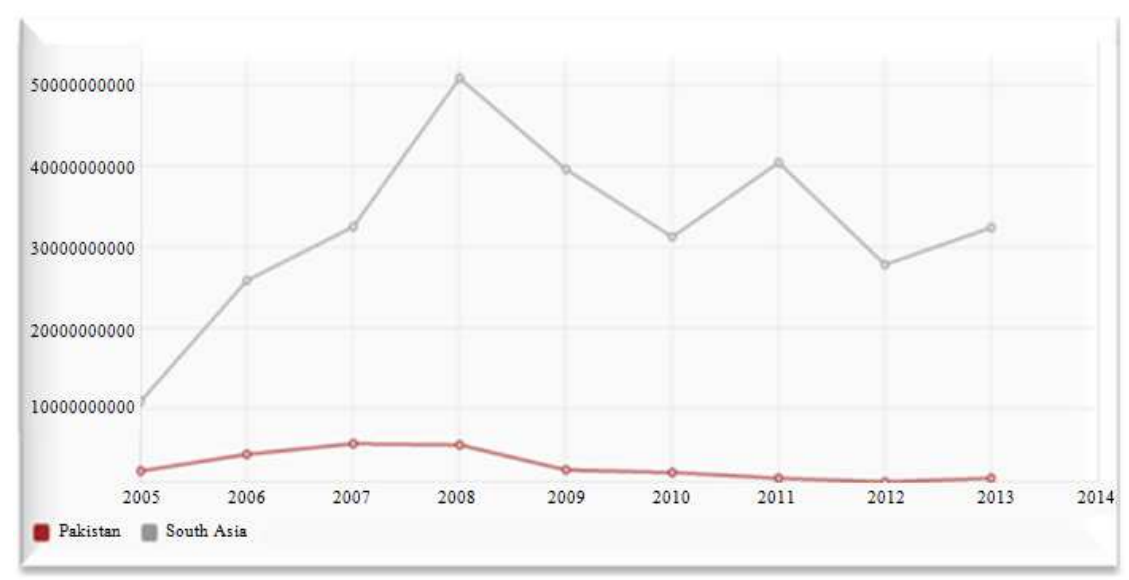

Fig. 3. Foreign direct investment, net inflows (BoP, current US\$). Source: World Bank

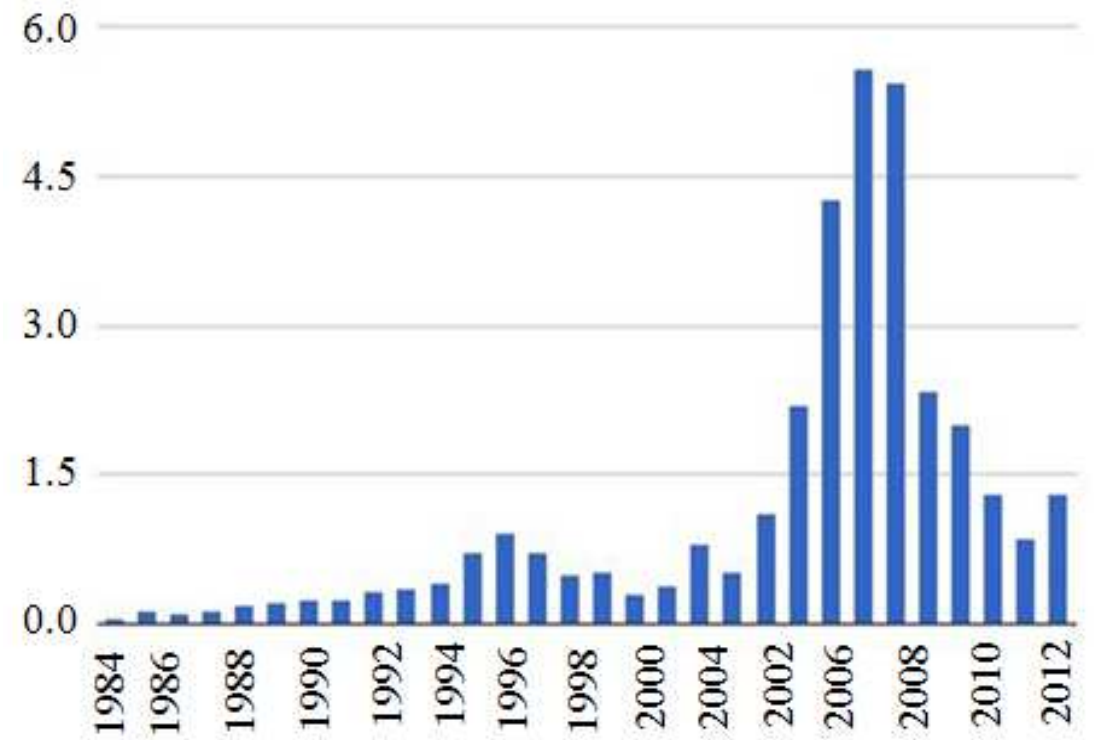

Fig. 4. Foreign Direct Investment in Pakistan Source: World Bank (Billions of US \$)

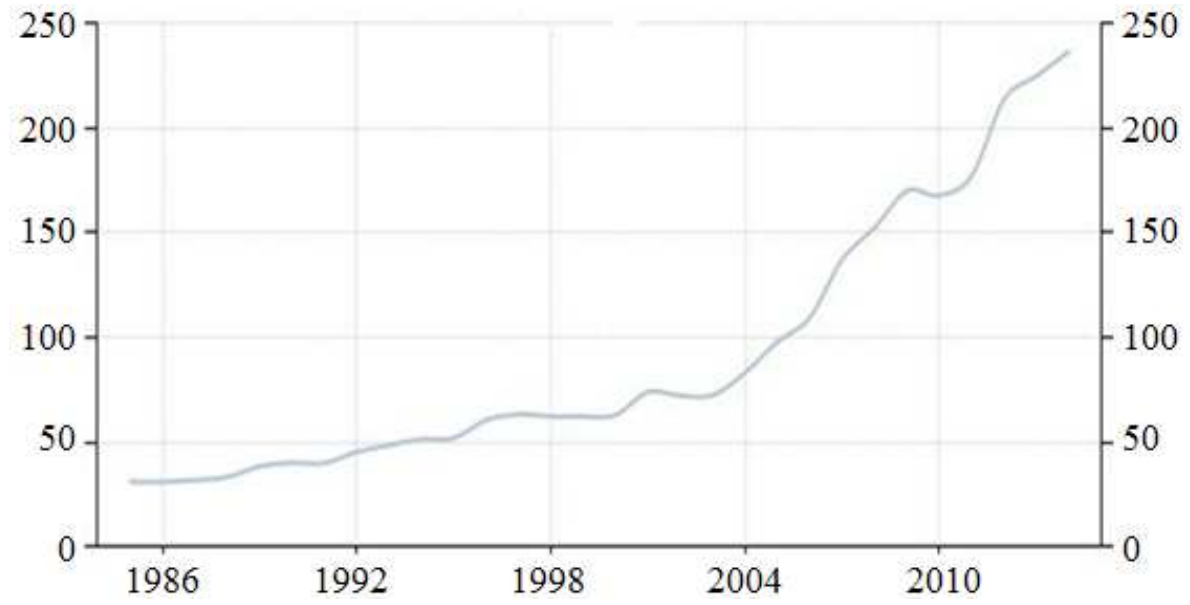

Fig. 5. Pakistan Gross Domestic Product (GDP- 1984-2014) (Billions of US Dollars) Source: World Bank Group 


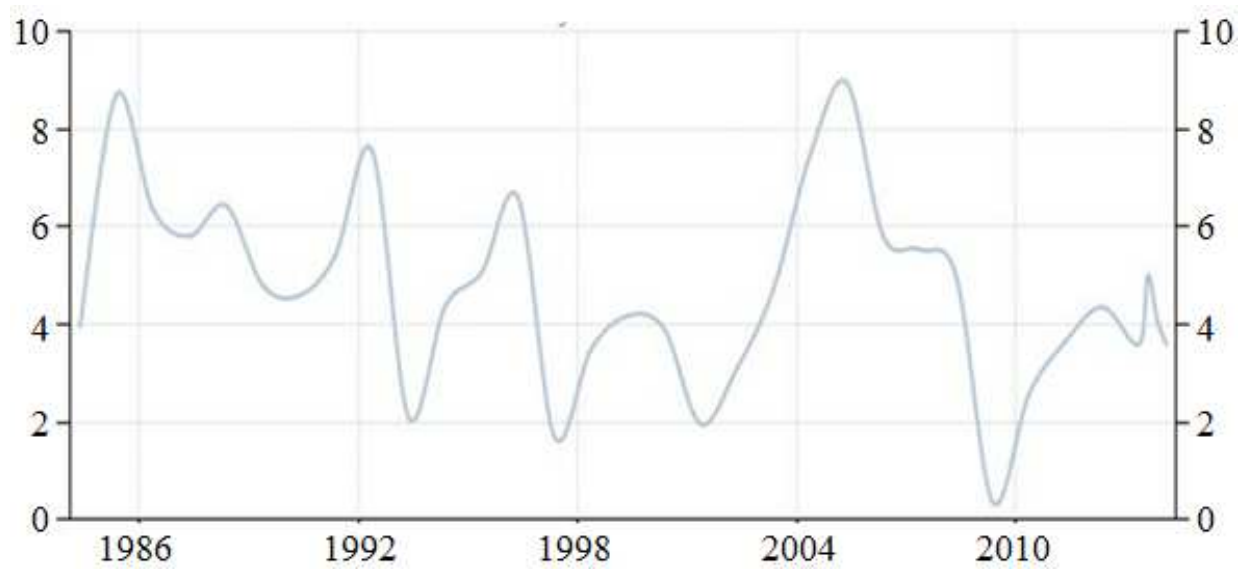

Fig. 6. Pakistan Gross Domestic Product Annual Growth rate 1984-2014) Percentage change in GDP Source: Pakistan Bureau of statistics

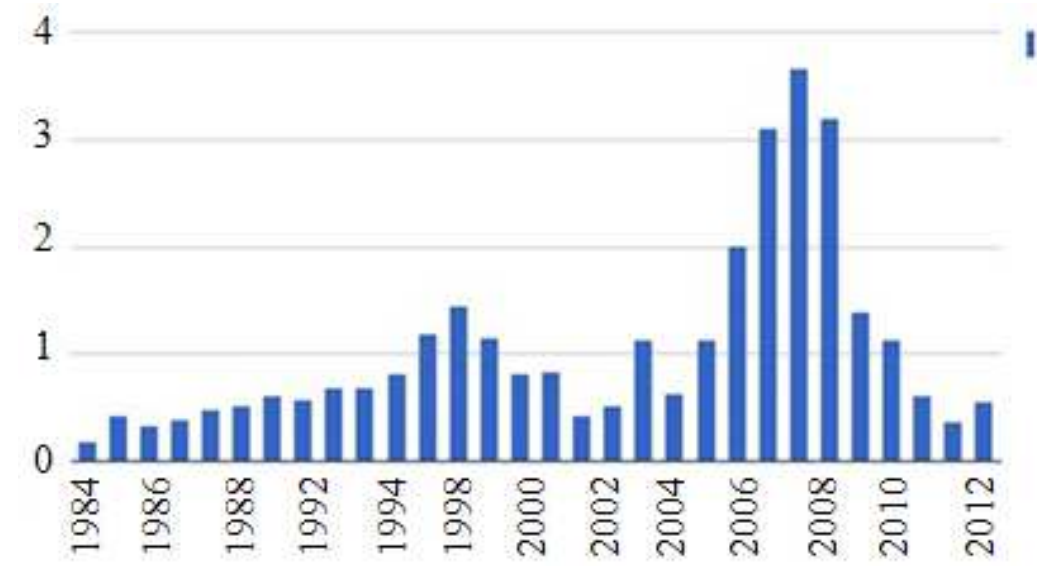

Fig. 7. Pakistan Foreign Direct Investment, percent of GDP Source: World Bank Group

\section{Purpose of Study and Methodology}

Purpose of this study is to analyze impact and relationship of foreign direct investment on gross domestic product. Data was collected from the World Bank source and time period of this study is last 30 years. In this study GDP is dependent variable and FDI is independent variable. We want to examine that if FDI increase then how much impact it has on the gross domestic product and is there positive relation or negative relation between these two. Multiple regression method is used in this study. One input foreign direct investment is used in the regression model. Figure 3, discribe foreigen direct investment and net inflows. In 2010 and 2012, it declines in South Asia due to several factors. According to Fig. 4, foreigen direct investment start increases from 2003 to 2008, but later decresesed is observed because of Political instability and overall situation of country.

Multiple regression model was used on E-view to find out Gross domestic product relation with foreign direct investment. Foreign direct investment is independent variable and Gross domestic product is dependent variable. Model is applied over the period of last thirty years. Foreign direct investment is used as output. Positive relation has been observed during multiple regression models. Coefficient value is 0.371 and $\mathrm{T}$ value is 14.99 so in other words we can say that change of one percent foreign direct investment means, $0.371 \%$ change in gross domestic product.

The average value for Pakistan during that period was 0.79 billion U.S. dollars with a minimum of -0 billion U.S. dollars in 1973 and a maximum of 1.31 billion U.S. dollars in 2013. Figure 5 shows GDP of Pakistan from 1984 to 2014. In 2014, GDP of Pakistan was 236.62 billion US dollars. Actually it represents $0.38 \%$ of world economy. Averaged GDP from last 53 years is 56.23 USD billion. Country is facing different issues and challenges from last many years. Mostly issues are related to political instability. Which is main cause of lower FDI in the country even country is full from natural resources. When high GDP and FDI were observed, it was due to stability in the country. Figure 6 describes GDP annual growth rate. 
Annual Growth rate of GDP from (1952-2014) is $4.91 \%$. While in first quarter of 2014, GDP growth rate is $3.60 \%$ according to Pakistan Bureau of Statistics.

\section{Analysis}

Pakistan has to face serious pressure as a developing country. From 2008, country economic policy has been changed and now growing much faster than before because of stable political environment and more relations to foreign investors in terms of taxes and facilities. FDI has played major role in the development of country and growth of economy. Foreign direct investment is also a source of employment. China is from one of those countries, who is investing billions of dollars in the country consider it as major key player.

Figure 7, describes about Foreigen direct investment and GDP relationship. In 1984, FDI was 0.18 of country GDP, while after one decade; it increases to $0.81 \%$ of the GDP. In 2006 and 2007, it has been observed highest. In 2006, FDI was $3.11 \%$ and 2007; it was 3.67 of country GDP. This high percentage was due to change is economic policies which attracted foreigner investors to invest in the country. After 2007, country is facing serious terrorism, so in 2008 it declines to 3.2 and in 2009, 1.39\% of GDP was observed because of financial crises. Accoding to trading economics, in 2014, Pakistan GDP is expanded 4.14\%. The lowest GDP of country was in 1952. Services sector is considered one of the major sector in the country.

\section{Conclusion}

The study has attempted to discuss foreign direct investment impact on Gross domestic product of Pakistan. Analysis suggests that in Pakistan, Foreign direct investment have a positive correction or impact of country gross domestic product. FDI plays an important and major role in the percentage of GDP. When there is increase in FDI, same time increase in GDP has been observed. In 2013, FDI was $0.55 \%$ of country GDP but in 2005, FDI was $2.01 \%$ of country GDP. FDI can play major role in the development of county and economy.

In terms of impediments to FDI inflow in Pakistan, some groups (Chinese investors, policy makers and enterprises) identified poor infrastructure as a major obstacle to FDI. These include shortage of power supply, transport, communication and gas. Despite recognizing some barriers, most of the investors appear to be satisfied about the present investment climate in Pakistan and expressed their interest in making further investment in the country. Majority of the respondents evaluated that the existing policies and government initiatives for FDI are satisfactory. However, they also suggested some measures to make Pakistan more investment friendly.

\section{Acknowledgement}

The corresponding author would like to provide his thanks to faculty of Business School, Hohai University and key staff members of Pakistan Bureau of Statistics.

\section{Author's Contributions}

Muddassar Sarfraz and Shuangqin Liu: Designed study objectives and fame work.

Muddassar Sarfraz: Participated in writing manuscript and data collection and analysis was done by both authors.

\section{Ethics}

No ethical conflicts will arise after publication of the manuscript.

\section{References}

Agrawal, P., 2000. Economic impact of foreign direct investment in South Asia. Indra Gandhi Institute of Development Research.

Ahmad, M.H., S. Alam and M.S. Butt, 2003. Foreign direct investment, exports and domestic output in Pakistan. Pak. Develop. Rev., 42: 715-723.

Caves, R.E., 1996. Multinational Enterprise and Economic Analysis. 2nd Edn., Cambridge University Press, Cambridge, ISBN-10: 0521478588, pp: 322.

Chen, J., 2000. Foreign direct investment. London: Macmillan Press.

Dunning, J. and A. Hamdani, 1997. The new globalism and developing countries.Tokyo; New York: United Nations University Press.

Findlay, R. 1978. Relative backwardness, direct foreign investment and the transfer of technology: A simple dynamic model. Q. J. Econ., 92: 1-16.

Falki, N., 2009. Impact of foreign direct investment on economic growth in Pakistan. Int. Rev. Bus. Res. Papers, 5: 110-120.

Gudaro, A.M., I.U. Chhapra and S.A. Sheikh, 2010. Impact of foreign direct investment on economic growth: A case study of Pakistan. J. Manage. Social Sci., 6: 22-30.

Herzer, D., S. Klasen and D.F. Nowak-Lehmann, 2008. In search of FDI-led growth in developing countries: The way forward. Econo. Modelling, 25: 793-810. DOI: 10.1016/j.econmod.2007.11.005

Kumar, N., 2002. Globalization and the quality of foreign direct investment. Oxford: Oxfor Press.

Mian and Alam, 2006. Foreign Direct investment and development: The Bangladesh Scenario. Australia: Manash University

Moosa, I.A., 2002. Foreign direct investment: Theory, evidence and practice, London: Palgrave. 
Muhammad, A.K., 2007. Foreign direct investment and economic growth: The role of domestic financial sector. Pakistan Institute of Development Economics.

Mottaleb, K.A., 2007. Determinants of foreign direct investment and its impact on economic growth in developing countries. Munich Personal RePEc Archive, Paper no. 9547.

Piggott, J. and M. Cook, 1999. International Business Economics: A European Perspective. 2nd Edn., Longman, New York, ISBN-10: 0582305802, pp: 429.
Reza, S., M.A. Rashid and M. Alam, 1987. Private Investment in Bangladesh. The University Press Ltd.: Dhaka.

Sethi, D., S.E. Guisinger, S.E. Phelan and D.M. Berg, 2003. Trends in foreign direct investment flows: A theoretical and empirical analysis. J. Int. Bus. Stud., 34: 315-326.

Shabbir, T. and A. Mahmood, 1992. The effects of foreign private investment on economic growth in Pakistan. Pak. Develop. Rev., 31: 831-841. 